\title{
The physical change of broiler meat given shrimp peptide extract (SPE) in drinking water during room temperature storage (post mortem)
}

\author{
SK Syahpura ${ }^{1^{*}}$, Y Sukaryana $^{1}$ and Susanti ${ }^{1}$ \\ ${ }^{1}$ Department of Animal Husbandry of Politeknik Negeri Lampung, Indonesia \\ *Corresponding author: ivisoraya@polinela.ac.id
}

\begin{abstract}
This study aims to determine the physical change of properties of broiler meat during storage at room temperature, This study used Schrimp Peptide Extract (SPE) in drinking water given to broiler who were 1 week old for 7 days in the morning. The research design used a completely randomized design with 4 SPE level treatments, T0 (0\%), T1 (1\%), T2 (2\%), T3 (3\%) in drinking water $(\mathrm{v} / \mathrm{v})$. Each treatment was repeated 5 times and each replication consisted of 12 animals randomly. The results showed that the treatment dose of Schrimp Peptide Extract (SPE) was significantly different $(\mathrm{P}<0.05)$ on the water binding capacity, cooking loss, and tenderness, and not significantly different from the $\mathrm{pH}$ of the broiler breast meat.
\end{abstract}

\section{Introduction}

One of the efforts in the livestock sector to encourage the success of this program is to create innovations to increase the quality and quantity of meat. One of the livestock that can achieve the goals is the broiler. The broiler is a type of broiler that has the main potential as a meat producer and is widely consumed by almost all levels of society in Indonesia. The demand for a healthy diet for healthy communities ask people to innovate in creating or finding products derived from waste (both agricultural, livestock, and fishery) conduct an assessment of the value of these waste commodities so that they can be used to improve livestock performance and remain pay attention to human safety. This research uses shrimp head waste that has been extracted called Shrimp Peptide Extract (SPE) and is a product derived from shrimp head waste extraction which has many benefits for livestock, namely as an anti-stress, boost the immune system, and support growth factors. Shrimp Peptide Extract contains high-quality protein (peptides), antioxidants, and organic acids. So far, shrimp head waste has not been utilized optimally.

Shrimp head waste has good potential to support livestock production performance (feed intake, final body weight (g/tail), feed conversion, mortality), carcass quality (cut weight, weight. carcass, percentage of carcass), physical quality of meat ( $\mathrm{pH}$, water holding capacity), and analysis of broiler blood to see the immunity resulting from using SPE in drinking water $(\mathrm{v} / \mathrm{v})$ given in the morning for 7 consecutive days. This research is important to carry out considering the increasing public awareness of healthy meat consumption, and research data on the use of shrimp peptide extract so far has been mostly used for aqua and shrimp feed products, so research and use of shrimp peptide extract still need to be assessed for poultry research. The use of shrimp peptide extract in rations and applicable 
drinking water is applied in people's farms considering that the waste comes from local shrimp which are affordable and easy to get.

\section{Material and Method}

The equipment used is a broiler cage, a triple beam balance, a knife, a tray, a $\mathrm{pH}$ meter, a feed box, a drinking bowl. The research was conducted in the broiler cage of Lampung State Polytechnic. The broiler used was the CP 707 strain, with as many as 200 individuals. The study used a completely randomized design with 4 SPE doses, namely T0 (0\%), T1 (1\%), T2 (2\%), T3 (3\%) in drinking water $(\mathrm{v} / \mathrm{v})$ given in the morning for 7 consecutive days. Each treatment was repeated 5 times and each replication consisted of 10 animals randomly. That was placed of Shrimp Peptide Extract [4] was carried out after a period of adaptation to maintenance for 1 week through a mixture in drinking water at $08.00 \mathrm{am}$.

The rations provided were the same, namely the commercial rations. as well as the provision of drinking water in the morning and evening for 4 weeks. The variables observed were production performance (feed intake, final body weight (gr/tail), feed conversion, mortality), carcass quality (cut weight, carcass weight, carcass percentage, $\mathrm{pH}$, water holding capacity). The experiment was carried out with an experimental method, using a completely randomized design, with 5 treatments and 4 replications, each consisting of 10 DOC strains of CP 707, as many as 200 individuals.

The differences between treatments were tested using the Duncan distance test observed variables acidity $(\mathrm{pH})$ of meat. Measuring the $\mathrm{pH}$ of the meat is done using a $\mathrm{pH}$ meter. Calibration of the tool is carried out before making measurements with buffer solutions 7 and 4 . The calibration process is carried out again if the $\mathrm{pH}$ meter will be used again if the tool has been turned off or off, or if there are a large number of samples being measured.

The calibrated tool is then used by sticking the tip of the $\mathrm{pH}$ meter into the meat sample so that a stable $\mathrm{pH}$ value is shown on the $\mathrm{pH}$ meter display screen, $\mathrm{pH}$ measurements were carried out 3 times to obtain an accurate value. Measurement of $\mathrm{pH}$ with different samples is carried out after washing the tip of the $\mathrm{pH}$ meter using distilled water, then drying it with a tissue. Water Holding Capacity (WHC) is determined by the Hamm method [10], namely by burdening or pressing 0.3 grams of raw meat samples placed on Whatman filter paper No. 43 and placed between two glass plates with a load of 35 $\mathrm{kg}$ for 5 minutes. This loading or pressing will cause free water to be released into the filter paper and form a circle. The area covered by the meat sample has become flattened (called the inner circle), and the area of the wet area around the filter paper and the meat sample is marked (outer ring).

The wet area is obtained by subtracting the wet area on the filter paper minus the area covered by the meat sample. Furthermore, the sample water content was determined using the gravimetric method. The higher the percentage of $\mathrm{mg} \mathrm{H}_{2} \mathrm{O}$, the lower the water-binding power produced. Previously, the water content test was carried out to calculate the water holding capacity. Value of cooking losses using Hamm's method, and tenderness with Warner Bratzler Shear Force. The data from the test results were analyzed using variance analysis with a unidirectional complete random design. The difference in means was tested with Duncan's New Multiple Range Test [11].

\section{Results and Discussion}

The physical quality of meat consists of $\mathrm{pH}$ value, cooking losses, water holding capacity, and meat tenderness.

\subsection{The $\mathrm{pH}$ value of the meat.}

The $\mathrm{pH}$ value is an important factor in determined the quality of meat. The results showed that the $\mathrm{pH}$ value of broiler meat with the addition of Shrimp peptide extract (SPE) above the $1 \%$ level was significantly different $(\mathrm{P}<0.05)$ (Table 1$)$. The normal $\mathrm{pH}$ value of broiler meat ranges from 5.96 to 6.07 [10], while the $\mathrm{pH}$ value of broiler meat from the research results ranges from 6.48 to 6.55 , and can be seen in Table 1. 
The higher the level of SPE addition in drinking water, it is thought that the lower the muscle glycogen levels[9]. Muscles with lower glycogen levels than normal muscles produce low lactic acid (40 $\mu \mathrm{M}$-lactate/g muscle with an ultimate $\mathrm{pH}$ of 6.2 compared to $100 \mu \mathrm{M}$-lactate/g muscle in normal meat) [7] and the aerobic glycolysis process which is still ongoing causes not much lactic acid to be produced so that the $\mathrm{pH}$ value of the meat is still quite high.

Water holding capacity (WHC) is a meat quality parameter that is closely related to water capacity, therefore water-binding capacity is related to quality parameters. Water binding capacity also shows the ability of meat to bind the water. The results of this study showed that the percentage of water holding capacity in broiler meat given SPE in drinking water was significantly different $(\mathrm{P}<0.05)$ (Table 1). [10] Reported that the WHC broiler meat at the age of 6 and 7 weeks was around $22.19 \%$ and $28.54 \%$, while the WHC broiler meat results from the study ranged from $30.25 \%$ to $35.92 \%$. The higher the level of SPE addition in drinking water, the more HE increases broiler meat. The increase in the percentage of WHC was caused by the addition of SPE in drinking water to affect fat in the meat. Edwards (1981) states that fat content has a negative relationship with protein levels.

Tabel 1. The average value of $\mathrm{pH}$, water holding capacity, cooking loss, and tenderness of meat of broiler chicken fed with the SPE in the drinking

\begin{tabular}{|c|c|c|c|c|}
\hline \multirow{2}{*}{ Variabels } & \multicolumn{4}{|c|}{ level of SPE (\%) } \\
\hline & 00 & 10 & 20 & 30 \\
\hline Value of $\mathrm{pH}$ & $6,50^{\mathrm{a}}$ & $6,55^{\mathrm{a}}$ & $6,53^{\mathrm{a}}$ & $6,48^{\mathrm{a}}$ \\
\hline Water-holding capacity (\%) & $30,23^{\mathrm{a}}$ & $34,66^{\mathrm{b}}$ & $35,92^{\mathrm{b}}$ & $35.75^{\mathrm{b}}$ \\
\hline Cooking loss $(\%)$ & $40,00^{\mathrm{a}}$ & $35,25^{\mathrm{b}}$ & $34.51^{\mathrm{b}}$ & $34.75^{\mathrm{b}}$ \\
\hline Tenderness $\left(\mathrm{kg} / \mathrm{cm}^{2}\right)$ & $4,78^{\mathrm{a}}$ & $3,56^{\mathrm{b}}$ & $3,30^{\mathrm{b}}$ & $3,30^{\mathrm{b}}$ \\
\hline
\end{tabular}

Note: a,b, different superscripts at the same row indicate significant differences $(P<0.01)$.

The water-holding capacity is also influenced by the $\mathrm{pH}$ of the meat [2], water that is retained in the muscles increases with increasing $\mathrm{pH}$. Water-binding capacity has a positive relationship with the $\mathrm{pH}$ value of meat [1]. The higher the level of SPE addition in drinking water, the higher the $\mathrm{pH}$ value of broiler meat. High $\mathrm{pH}$ values can improve the water binding capacity [4]. the low $\mathrm{pH}$ value of meat induces an open structure of the meat which reduces the water holding capacity, and the high $\mathrm{pH}$ value of the meat induces a closed meat structure water holding capacity is. [9] States that at a $\mathrm{pH}$ that is higher or lower than the isoelectric point of meat proteins, WHC increases, because, at a $\mathrm{pH}$ lower than the isoelectric point of meat proteins, there is an excess of positive charge which results in myofilament rejection and gives more lots of room for water molecules.

\subsection{Cooking loss}

Cooking shrinkage is an important determinant of meat quality because it is associated with how much water is lost and nutrients that dissolve in water due to the effects of cooking. A smaller percentage of cooking loss means less water loss and water-soluble nutrients. Likewise, on the contrary, the greater the percentage of cooking losses, the more water is lost and nutrients that dissolve in water. The results showed that the percent cooking loss of broiler meat fed with the addition of SPE in drinking water above the $1.0 \%$ level was significantly different $(\mathrm{P}<0.05)$ (Table 1). [10] Reported that the cooking losses of broiler meat at the age of 6 and 7 weeks were around $24.89 \%$ and $34.57 \%$, while the cooking losses of broiler meat from the study ranged from $33.75 \%$ to $40 \%$. The higher the level of SPE addition in drinking water, the lower the cooking losses of broiler meat. Quality meat has low cooking losses [10] because the loss of nutrients during cooking will be less and feed consumption can affect the number of cooking losses. This is because the addition of SPE in drinking water has an effect on fat in the meat. so it is suspected that during the cooking process there is less broiler meat fat, 
more cooking losses are caused by the melting of fat. Cooking losses have a negative relationship with water holding capacity [10]. Meat with high WHC will have low cooking losses. The highest cooking loss, namely $40.00 \%$, was obtained at the addition of SPE $0 \%$ in drinking water, this was due to the low $\mathrm{pH}$ value of the meat and WHC, thus increasing the cooking loss of meat. The lowest cooking loss of meat, namely $33.75 \%$, was obtained at the level of adding $3.0 \%$ SPE in drinking water, this was due to an increase in the $\mathrm{pH}$ value of meat and WHC, thus reducing cooking losses.

\subsection{Meat tenderness}

Tenderness is one of the qualities of meat for consumer acceptance and usually, consumers want soft meat. The results showed that the tenderness level of broiler meat fed with the addition of SPE above the $1 \%$ level was significantly different $(\mathrm{P}<0.05)$ (Table 1). Lyon et al. (2004) reported that the tenderness of broilers ranged from $1.82 \mathrm{~kg} / \mathrm{cm} 2$ to $2.19 \mathrm{~kg} / \mathrm{cm} 2$, while the level of the tenderness of the broiler meat from the study ranged from $3.30 \mathrm{~kg} / \mathrm{cm}^{2}$ to $3.78 \mathrm{~kg} / \mathrm{cm}^{2}$. The difference in the level of meat tenderness is caused by the addition of SPE in drinking water affects the $\mathrm{pH}$, WHC, and cooking loss of broiler meat. The higher level of SPE addition in drinking water, the lower the breaking power value of the meat, the more tender the meat will be [8].

The highest breaking power of meat $3.78 \mathrm{~kg} / \mathrm{cm} 2$, was obtained at the level of the addition of SPE $0 \%$ in drinking water, this was due to the low $\mathrm{pH}$ value of the meat and $\mathrm{WHC}$ as well as the increase in cooking losses which increased the braking power of the meat. The lowest breaking power of meat was obtained at the level of adding SPE $2.0 \%$ and $3 \%$ in drinking water, namely $3.30 \mathrm{~kg} / \mathrm{cm}^{2}$, this is because the meat in the SPE treatment of $2.0 \%-3 \%$ had a high $\mathrm{pH}$ value of meat and WHC. as well as lower cooking losses of meat compared to other treatments. [10] states that meat with a high $\mathrm{pH}$ value usually contains more juice so that the meat is more tender.

\section{Conclusions}

From the results of the study, it can be concluded that the addition of Shrimp Peptide Extract (SPE) in drinking water up to a level of $3.0 \%$ can improve the physical quality, namely water holding capacity, cooking losses, and tenderness.

\section{References}

[1] Allen, C.D., D.L. Fletcher, J.K. Northcutt, and S.M. Russell. 1998. The relationship of broiler breast color to meat quality and shelf-life. Poultry Sci. 77:361-366

[2] Alvarado, C. and S. McKee. 2007. Marination to improve functional properties and safety of Poultry meat. J. Appl. Poult. Res. 16:113-120.

[3] Bouton, P.E., P.V. Harris, and W.R. Shorthose. 1971. Effect of ultimate pH upon the Water holding capacity and tenderness of mutton. J. Food. Sci. 36:435-439.

[4] Buckle, K. A., R. A. Edwards, G. H. Fleet, and F. M. Wooton. 1985. Ilmu Pangan. Penerjemah Purnomo, H. dan Adiono. Cetakan Ke-1. Universitas Indonesia Press, Jakarta.

[5] Edwards, H.M. Jr. 1981. Carcass composition studies. 3. Influence of age, sex, and calorie protein contents of the diet on carcass composition of Japanese quail. Poultry Sci. 60: 25062512

[6] Lawrie, R.A. 2003. Ilmu Daging. Edisi Ke-5. Diterjemahkan oleh Parakkasi, A.,dan Y. Amwila. Universitas Indonesia Press, Jakarta.

[7] Maltin, C., D. Balcerzak, R. Tilley, and M. Delday. 2003. Determinants of meat quality tenderness. Proceedings of the Nutrition Society 62:337-347.

[8] Maruddin, F. 2004. Kualitas daging sapi asap pada lama pengasapan dan penyimpanan. Jurnal Sains dan Teknologi Vol. 4(2):83-90.

[9] Soeparno. 2005. Ilmu dan Teknologi Daging. Cetakan Ke-4. Gadjah Mada University Press, Yogyakarta.

[10] --------, 2011. Tehnologi Pengawasan Daging. Fakultas Teknologi Pertanian Bogor, Bogor. 
[11] Steel, R.G.D. dan J.H.Torrie. 1993.Prinsip dan Prosedur Statistik Suatu Pendekatan Biometrik. PT Gramedia Pustaka Utama, Jakarta. 